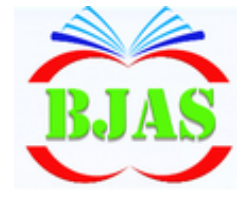

ISSN $1814-5868$
Available online at http://bjas.bajas.edu.iq

https://doi.org/10.37077/25200860.2020.33.1.15

College of Agriculture, University of Basrah

Basrah J. Agric. Sci. 33(1): 200-212, 2020
Basrah Journal
of Agricultural
Sciences

E-ISSN: 2520-0860

\title{
Effect of Omega-3 Fatty Acids (EPA / DHA) and Vitamin E Addition on the Growth Performance and the Larvae Performance of Cyprinus carpio L.
}

\author{
Osamah A. Salih ${ }^{1}$, Adel Y. Al-Dubakel ${ }^{2 *}$ \& Ali I. Gowdet ${ }^{3}$ \\ ${ }^{1}$ Directory of Basrah Agriculture, Ministry of Agriculture, Iraq. \\ ${ }^{2}$ Aquaculture Unit, College of Agriculture, University of Basrah,Iraq \\ ${ }^{3}$ Department of Fisheries and Marine Resources, College of Agriculture, University of Basrah, Iraq \\ *Corresponding author: aaldubakel22@gmail.com
}

Received 22 March 2020; Accepted 4 June 2020; Available online 27 June 2020

\begin{abstract}
This study was conducted in earthen ponds of shrimp hatchery belonging to the Basrah Agricultural Directorate, to find out the effect using of food additives omega-3 and Vitamin E on the performance of the growth and the quality of the produced larvae of the common carp Cyprinus carpio L.. Three treatments were used, the first treatment (T1) represented control without any food additives, the second treatment (T2) contained $5 \mathrm{gm} . \mathrm{Kg}^{-1}$ diet of omega-3 fatty acids and the third treatment (T3) contained Vit. E was added at $200 \mathrm{mg} \cdot \mathrm{Kg}^{-1}$ diet. The experiment lasted for 82 days. For each treatment three replicate were used and six common carp brood stock in each replicate. The productive parameters (body weight, weight gain, feed conversion rate, feed efficiency ratio $\%$ and specific and relative growth rate\%) were measured. Results indicated an improvement in all production parameters and in the feed conversion efficiency of for T2 and T3, compared with the T1. The weight gain (526.39 $\mathrm{gm}$.fish $\left.{ }^{-1}\right)$, feed conversion rate was 3.61 and feed efficiency ratio was $28.13 \%$ for the $\mathrm{T} 2$ which showed a significant differences $(\mathrm{P}<0.05)$ compared to the control, while T3 did not show significant differences $(\mathrm{P}>0.05)$ in comparison with both treatments $\mathrm{T} 1$ and $\mathrm{T} 2$; the specific and relative growth rate for $\mathrm{T} 2$ were $0.32 \%$. day $^{-1}$ and $30.81 \%$.day ${ }^{-1}$ respectively showed also a significant differences $(\mathrm{P}<0.05)$ compared with the control. These results showed that addition Vit. E to the diet improved the production parameters of common carp larvae better than in omega-3 and control treatments. The study concluded that addition omega- 3 fatty acids at a concentration of $5 \mathrm{gm} \mathrm{Kg}^{-1}$, and Vit. E at a concentration of $200 \mathrm{mg} \mathrm{kg}^{-1}$ to the diet enhanced the growth rates of common carp and improved larvae production.
\end{abstract}

Key words: Cyprinus carpio, common carp, omega-3 fatty acids (EPA / DHA), Vitamin E.

\section{Introduction}

Fishes represent about $17 \%$ of the animal protein consumed by the world's population. Moreover, fish provided for about 3.2 billion people, and provided approximately $20 \%$ of the average per capita animal protein intake; fishes is a very nutritional source and especially helps to compensation the nutrient deficiency (FAO, 2018). Scientific reports indicated that the functions of essential fatty acids of the two groups i.e. omega- 3 and omega- 6 are fluctuated after knowing that high doses of essential fatty acids from omega- 6 have some risks affecting 


\section{Salih et al. / Basrah J. Agric. Sci., 33(1): 200-212, 2020}

health when the ratio increased from 1:1 during development to 20:1 at present or even higher (Simopoulos, 2016). Increasing in omega-6 intake include cancerous tumors, formation of self-thrombosis, and the response to infections, so recommendations for increasing $n-3$ and reducing $n-6$ consumption have been proposed by nutritionists (Zhang et al., 2020). Health benefits of essential omega-3 fatty acids, especially Docosahexaenic (DHA, C22:6 n-3) and Eicosapenaenic acid (EPA, C20:5 n-3) which found in fish oil and alpha-linolenic acid (ALA, C18:3 n-3) that found in vegetable oils contradict the harmful effects of omega- 6 fatty acids (Burdge et al., 2002). Omega-3 was considered an essential fatty acid for humans as final consumer of fish (Ramezani et al., 2012).

Determining the exact amount of requirement of essential fatty acids is difficult because it depends on the quality and source of fat, omega-3/omega- 6 ratio in food and fatty acid metabolism in the body (Bezard et al., 1994). The dietary important of the highly unsaturated fatty acids (HUFA) for marine fish was known earlier (Sargent et al., 1997).

Vit. E is one of the most important nonenzymatic soluble antioxidants in fat, as it works to remove the oxygen root and thus is the first line in removing fat oxidation (Puangkaew et al., 2005). Naturally it consists of from alpha-tocopherol, beta-tocopherol, deltatocopherol, Kama-tocopherol, as well as alphatocotrienol, beta-tocotrienzole, delta-tocotrienol (Sen et al., 2006); researchers indicated the importance of Vit. E in improving the immune response of fish, as it modifies the physiological changes of rainbow trout Oncorhynchus mykiss when fed on diets containing high concentrations of unsaturated fat (Puangkaew et al., 2005). Frischknecht et al. (1994) found that a deficiency of Vit. E in the diet of rainbow trout leads to poor growth.

The aim of the present study was to evaluate the effect of omega-3 fatty acids (EPA/DHA) and Vit. E on growth performance and the larvae quality of common carp Cyprinus carpio.

\section{Materials \& Methods}

\section{Study site}

The research work was implemented for all experiments in shrimp hatchery belonging to the Basrah Agricultural Directorate for the period from 29th October.2018 to 17th July 2019. The study site is located in the northern Basrah Governorate, $21 \mathrm{~km}$ from the city Centre. The hatchery area is one hectare consisting of four earthen ponds, $(20 \times 80 \mathrm{~m})$ and depth of $1.5 \mathrm{~m}$. In addition, it contains a hatching hall with an area of $8 \times 12 \mathrm{~m}$.

\section{Fish of the experiment}

A total of 54 individuals of common carp brood stock were used in all study experiments, since it considered the primary breeding fish achieved in Iraq, brought from a local floating cages fish farms in Al-Qurnah city, Fishes were transported to the study site by means of pickup. Fishes were sterilized by saline solution $(5 \% \mathrm{NaCl})$ for 5-10 minutes as soon as they arrived at the work site to get rid of fungi and other pathogenic organisms that may stuck on the skin or gills.

The larvae were obtained from the reproduction of the same fishes used in the growth experiment. For each treatment 10,000 larvae were stocked in triplicate at the beginning of the experiment. After experiment completion, the pond was emptied and all the 
larvae were caught to measure weight and to calculate the survival rate.

\section{Design of the experiment}

The experiment was designed with three treatments (control T1, omega-3 T2 and Vit. E T3) each has three replications, six individuals for each replication. Nine cages that made from polypropylene random copolymer (PPR pipe) material were manufactured for the three treatments (length $\times$ width $\times$ height $3 \times 1.7 \times 1.8$ $\mathrm{m})$, surrounded by nets with $10 \times 10 \mathrm{~mm}$ mesh size, to isolate the three treatments and easy monitoring and feeding of the fish. These cages were placed inside the earthen ponds which filled with water to one meter height. The fish were randomly distributed in nine cages made by PPR. The brood stock was fed with $3 \%$ body weight (BW), two times a day, one at 8 $\mathrm{AM}$ and the second at $2 \mathrm{PM}$. The amount of feed was adjusted according to the changing of the biomass every two weeks. This experiment continued from 28 October 2018 to 30 March 2019.
The second experiment carried out in earthen ponds to cultivate the produced larvae with an area of $80 \times 10 \times 1.5 \mathrm{~m}$, as the ponds were prepared by removing the sediments and plants. Every pond was divided into three treatments, each with three replication in an area of $9 \times 10$ $\times 1.5 \mathrm{~m}$ and separated by iron pegs and divided by fine mesh. This experiment continued for 62 days from 28 April to 23 July 2019.

\section{Experimental diets:}

The diets that used in the experiments were prepared after calculating the percentages of each feed component and mixing it for homogeneity. The experimental diets (the three treatments) were manufactured in the Feed factory in the College of Agriculture, University of Basra, as shown in table (1), the chemical analysis of the diets were carried out in the quality control laboratory of the Animal Resources Department of the Ministry of Agriculture.

Table (1): Ingredients and chemical analysis of the experimental diets.

\begin{tabular}{|ccccccc|}
\hline & \multicolumn{2}{c}{ Control (T1) } & \multicolumn{2}{c|}{ Omega -3 (T2) } & \multicolumn{2}{c|}{ Vit. E (T3) } \\
\cline { 2 - 7 } Ingredients & Brood stock & Larvae & Brood stock & Larvae & Brood stock & Larvae \\
\hline Fish meal & 30 & 35 & 30 & 35 & 30 & 35 \\
\hline Wheat flour & 45 & 40 & 45 & 40 & 45 & 40 \\
\hline Wheat bran & 23 & 25 & 23 & 25 & 23 & 25 \\
\hline Sunflower oil & 2 & 2 & 2 & 2 & 2 & 2 \\
\hline *Omega -3 (g. $\left.\mathrm{Kg}^{-1}\right)$ & 0 & 0 & 5 & 5 & 0 & 0 \\
\hline Vit. E (mg.Kg $\left.\mathrm{Kg}^{1}\right)$ & 0 & 0 & 0 & 0 & 200 & 200 \\
\hline Moisture & 10.1 & 10.1 & 9.7 & 9.5 & 8.8 & 9.4 \\
\hline Crud protein & 21.9 & 22.7 & 23.3 & 25.8 & 22.8 & 23.8 \\
\hline Crud lipid & 4.1 & 4.9 & 5.5 & 6.7 & 4.8 & 5.4 \\
\hline Crud fibre & 4.6 & 5.8 & 4.1 & 6.6 & 3.9 & 6.9 \\
\hline Nitrogen Free & 59.3 & 56.5 & 57.4 & 51.4 & 59.7 & 54.5 \\
Extract (NFE) & & & & & & \\
\hline
\end{tabular}

*(EPA and DHA) 
Salih et al. / Basrah J. Agric. Sci., 33(1): 200-212, 2020

\section{Design of the experiment}

The experiment was designed with three treatments (control T1, omega-3 T2 and Vit. E T3) each has three replications, six individuals for each replication. Nine cages that made from polypropylene random copolymer (PPR pipe) material were manufactured for the three treatments (length $\times$ width $\times$ height $3 \times 1.7 \times 1.8$ $\mathrm{m})$, surrounded by nets with $10 \times 10 \mathrm{~mm}$ mesh size, to isolate the three treatments and easy monitoring and feeding of the fish. These cages were placed inside the earthen ponds which filled with water to one meter height. The fish were randomly distributed in nine cages made by PPR. The brood stock was fed with $3 \%$ body weight (BW), two times a day, one at 8 $\mathrm{AM}$ and the second at $2 \mathrm{PM}$. The amount of feed was adjusted according to the changing of the biomass every two weeks. This experiment continued from 28 October 2018 to 30 March 2019 .

The second experiment carried out in earthen ponds to cultivate the produced larvae with an area of $80 \times 10 \times 1.5 \mathrm{~m}$, as the ponds were prepared by removing the sediments and plants. Every pond was divided into three treatments, each with three replication in an area of $9 \times 10$ $\times 1.5 \mathrm{~m}$ and separated by iron pegs and divided by fine mesh. This experiment continued for 62 days from 28 April to 23 July 2019 .

\section{Experimental diets:}

The diets that used in the experiments were prepared after calculating the percentages of each feed component and mixing it for homogeneity. The experimental diets (the three treatments) were manufactured in the Feed factory in the College of Agriculture, University of Basra, as shown in table (1), the chemical analysis of the diets were carried out in the Quality Control Laboratory of the Animal Resources Department of the Ministry of Agriculture.

\section{Productive parameters}

The following equations were used to describe the growth performance of brood stock:

Weight gain:

$$
\mathrm{WG}=\mathrm{W} 2\left(\mathrm{~g} . \mathrm{fish}^{-1}\right)-\mathrm{W} 1\left(\mathrm{~g} . \mathrm{fish}^{-1}\right)
$$

Relative Growth Rate:

$$
\mathrm{RGR}=\frac{\left(\mathrm{W} 2 \mathrm{~g} \cdot \mathrm{fish} \mathrm{H}^{-1}-\mathrm{W} 1 \mathrm{~g} \cdot \mathrm{fish}^{-1}\right)}{W 1} \times 100
$$

Specific Growth Rate:

$\mathrm{SGR}=\frac{\left(\operatorname{lnW} 2 \mathrm{~g} \cdot \mathrm{fish}^{-1}-\operatorname{lnW} 1 \mathrm{~g} \cdot \mathrm{fish}^{-1}\right)}{T 1-T 2} \times 100$

Where lnw2 is the natural logarithm of the final weight at the time $T 2, \ln w 1$ is the natural logarithm of the initial weight at the time T1and $\mathrm{T} 2-\mathrm{T} 1$ is the period between the two weights.

1- Feed Conversion Rate:

$$
\mathrm{FCR}=\frac{R}{W G}
$$

2- Feed Efficiency Rate:

$$
\text { FER }=\frac{W G}{R}
$$

Where R: weight of dry feed intake. WG: wet weight gain (live weight of fish).

3- Survival rate:

Survival rate $=\frac{\text { No.of larvae alive }}{\text { Total No.of larvae stocked }} \times 100$

For fish larvae all the above parameters were also used, but RGR was modified, due to the 
Salih et al. / Basrah J. Agric. Sci., 33(1): 200-212, 2020

large differences between initial and final weight (Myszkowski, 1997) as follow:

$$
\mathrm{RBR}=100\left(e^{\frac{S G R}{100}}-1\right)
$$

Nitrogen free extract was calculated according to New (1987) as follow:

$\% \mathrm{NFE}=\% \mathrm{DM}-(\% \mathrm{EE}+\% \mathrm{CP}+\% \mathrm{ASH}+\% \mathrm{CF})$

Where: $\mathrm{NFE}=$ nitrogen free extract

$\mathrm{DM}=$ Dry matter

$\mathrm{EE}=$ ether extract or crude lipid

$\mathrm{CP}=$ crude protein

$\mathrm{CF}=$ crude fibre

\section{Statistical analysis:}

All parameters were tested using one-way analysis of variance (ANOVA). Significant results $(\mathrm{P}<0.05)$ were tested using LSD to test significant difference between means. This statistical analysis was completed with the computer software SPSS package.

\section{Results}

In the first experiment where fish reared in three treatments (control, omega-3 fatty acid group, Vit. E) with an average initial individual weight (1476.74, 1699.17 and 1723.06 g.fish $^{-1}$ ) respectively. It was noticed in table (2) that the average of final weight of the T2 (omega-3) were higher than $\mathrm{T} 1$ but there was no significant differences $(\mathrm{P}>0.05)$ between them. It was found that from the statistical analysis refers to a significant differences $(\mathrm{P}<0.05)$ in the total and daily weight showing existing increase between treatment $\mathrm{T} 1$ and $\mathrm{T} 2$ which were 287.23 and 526.39 g.fish $^{-1}$ respectively, while it was not significant differences $(\mathrm{P}>$
0.05) between treatment $\mathrm{T} 3$ and both other treatments (Table 2).

Results indicated that the specific and relative growth rates of the $\mathrm{T} 1$ was $0.21 \% . \mathrm{d}^{-1}$ and $19.09 \%$ respectively, while for the $\mathrm{T} 2$ it was $0.33 \% . \mathrm{d}^{-1}$ and $30.82 \%$ respectively and $30.82 \%$ and for treatment T3 recorded $0.25 \%$. $\mathrm{d}^{-1}$ and $22.70 \%$ respectively. Results of using omega-3 (T2) showed a significant differences $(\mathrm{P}<0.05)$ for the specific growth rate and the relative growth rate with the $\mathrm{T} 1$ and $\mathrm{T} 3$ treatments, while statistical analysis showed that there was no significant differences ( $\mathrm{P}>0.05)$ between the T1 and T3 (Table 2).

Treatment T1 recorded 5.58 in feed conversion rate and $18.37 \%$ in feed efficiency ratio, while in T2 it was 3.61 and $28.13 \%$ for food conversation and food efficiency respectively and, treatment $\mathrm{T} 3$ reached 4.5 in food conversion rate and $22.96 \%$ in a food efficiency ratio. The statistical analysis showed significant differences $(\mathrm{P}<0.05)$ between treatment $\mathrm{T} 1$ and $\mathrm{T} 2$ but no significant differences $(\mathrm{P}>0.05)$ between $\mathrm{T} 3$ with other two treatments (Table 2).

For larvae, the experiment was conducted to compare between $\mathrm{T} 1$ control and the addition of the omega-3 (T2) fatty acid group and Vit. E (T3) in the diets of common carp larvae that reared in earthen ponds and their effect on growth performance and survival rate. 
Salih et al. / Basrah J. Agric. Sci., 33(1): 200-212, 2020

Table (2): Productive parameters of common carp stock fed on three experimental diets $($ Mean \pm SD).

\begin{tabular}{|c|c|c|c|}
\hline \multirow[t]{2}{*}{ Parameters } & \multicolumn{3}{|c|}{ Treatments } \\
\hline & Control (T1) & Omega-3 (T2) & Vitamin E (T3) \\
\hline IW (g) & $\begin{array}{c}1476.74 \mathrm{a} \\
\pm 193.58 \\
\end{array}$ & $\begin{array}{c}1699.17 \mathrm{a} \\
\pm 350.99 \\
\end{array}$ & $\begin{array}{c}1723.06 \mathrm{a} \\
\pm 168.15\end{array}$ \\
\hline $\mathrm{FW}(\mathrm{g})$ & $\begin{array}{c}1763.97 \mathrm{a} \\
\pm 288.56 \\
\end{array}$ & $\begin{array}{c}2225.56 \mathrm{a} \\
\pm 47.10 \\
\end{array}$ & $\begin{array}{c}2119.17 \mathrm{a} \\
\pm 279.47 \\
\end{array}$ \\
\hline WG (g) & $\begin{array}{c}287.23 \mathrm{a} \\
\pm 95.01\end{array}$ & $\begin{array}{l}526.39 \mathrm{~b} \\
\pm 126.61\end{array}$ & $\begin{array}{c}396.11 \mathrm{ab} \\
\pm 111.68\end{array}$ \\
\hline DWG $\left(\mathrm{g}^{-\mathrm{d}^{-1}}\right)$ & $\begin{array}{l}3.50 \mathrm{a} \\
\pm 1.59\end{array}$ & $\begin{array}{c}6.42 \mathrm{~b} \\
1.54 \pm 26\end{array}$ & $\begin{array}{c}4.83 \mathrm{ab} \\
\pm 1.36\end{array}$ \\
\hline S G R $\left(\% . d^{-1}\right)$ & $\begin{array}{l}0.21 \mathrm{a} \\
\pm 0.04\end{array}$ & $\begin{array}{c}0.33 \mathrm{~b} \\
\pm 0.01264\end{array}$ & $\begin{array}{c}0.25 \mathrm{ab} \\
\pm 0.04\end{array}$ \\
\hline R G R \% & $\begin{array}{c}19.09 \mathrm{a} \\
\pm 4.17 \\
\end{array}$ & $\begin{array}{c}30.82 \mathrm{~b} \\
\pm 1.35625\end{array}$ & $\begin{array}{c}22.70 \mathrm{ab} \\
\pm 4.49\end{array}$ \\
\hline F C R & $\begin{array}{l}5.58 \mathrm{a} \\
\pm 1.12\end{array}$ & $\begin{array}{c}3.61 \mathrm{~b} \\
\pm 0.55895\end{array}$ & $\begin{array}{c}4.52 \mathrm{ab} \\
\pm 1.05\end{array}$ \\
\hline F E R \% & $\begin{array}{c}18.37 \mathrm{a} \\
\pm 3.50\end{array}$ & $\begin{array}{c}28.137 \mathrm{~b} \\
\pm 4.02\end{array}$ & $\begin{array}{c}22.97 \mathrm{ab} \\
\pm 5.44\end{array}$ \\
\hline
\end{tabular}

Data with different superscripts are significantly different $(\mathrm{P}<0.05)$

Table (3) shows the initial, final weight of common carp larvae fed on two food additives. No significant differences $(\mathrm{P}>0.05)$ among the three treatments were noticed. While the results of the statistical analysis of the total and daily weight gains showed significant differences $(\mathrm{P}<0.05)$ among the three treatments in daily weight gain only. The specific growth rate showed significant differences $(\mathrm{P}<0.05)$ among the three treatments, but only significant differences $(\mathrm{P}<0.05)$ between $\mathrm{T} 3$ and other two treatments was obvious for relative biomass growth rate. In all above parameters, T3 exhibited high values.

Feed conversion rate and food efficiency ratio of control and the food additives diets showed in table (3), by 5.15 and $19.48 \%$ respectively in $\mathrm{T} 1$, and 3.33 and 32.25 respectively in $\mathrm{T} 2$ and $\%$ and 3.72 and $28.47 \%$ respectively in $\mathrm{T} 3$. The statistical analysis of the feed conversion rate and the feed efficiency ratio showed no significant differences ( $>0.05)$ among the three treatments .

Survival rate was $3.77 \%$ for $\mathrm{T} 1$ and 23.77 $\%$ for $\mathrm{T} 2$ but there was no significant differences (P> 0.05), While T3 recorded highest survival rate $(23.77 \%)$, which differ significantly $(\mathrm{P}<0.05)$ with the other two treatments. 
Salih et al. / Basrah J. Agric. Sci., 33(1): 200-212, 2020

Table (3) Productive parameters of common carp larvae fed on three experimental diets (Mean \pm SD).

\begin{tabular}{|lccc|}
\hline & & & \\
& & & \\
& & & \\
& & & \\
& Control (T1) & Omega-3 (T2) & vitamin E (T3) \\
\cline { 2 - 4 } & & & \\
\hline IW (mg) & $57.59 \mathrm{a}$ & $169.02 \mathrm{a}$ & $20.51 \mathrm{a}$ \\
& \pm 21.77 & \pm 16.48 & \pm 2.10 \\
\hline FW (mg) & $6254.76 \mathrm{a}$ & $3745.24 \mathrm{a}$ & $8976.54 \mathrm{a}$ \\
& \pm 171.14 & \pm 1168.73 & \pm 5101.33 \\
\hline WG (mg) & $6197.17 \mathrm{a}$ & $3576.22 \mathrm{a}$ & $8956.03 \mathrm{a}$ \\
& \pm 159.40 & \pm 1152.37 & \pm 5099.40 \\
\hline DWG (mg.d $\left.{ }^{-1}\right)$ & $108.72 \mathrm{a}$ & $62.74 \mathrm{~b}$ & $157.12 \mathrm{c}$ \\
& \pm 2.80 & \pm 20.23 & \pm 89.46 \\
\hline S G R (\%.d $\left.{ }^{-1}\right)$ & $8.30 \mathrm{a}$ & $5.38 \mathrm{~b}$ & $10.50 \mathrm{c}$ \\
& \pm 0.59 & \pm 0.37 & \pm 0.76 \\
\hline R B R \% & $133.78 \mathrm{a}$ & $149.09 \mathrm{a}$ & $384.40 \mathrm{~b}$ \\
& \pm 67.72 & \pm 87.03 & \pm 93.40 \\
\hline F C R & $5.15 \mathrm{a}$ & $3.34 \mathrm{a}$ & $3.73 \mathrm{a}$ \\
& \pm 0.401 & \pm 1.059 & \pm 1.102 \\
\hline F E R \% & $19.49 \mathrm{a}$ & $32.25 \mathrm{a}$ & $28.47 \mathrm{a}$ \\
& \pm 1.462 & \pm 11.053 & \pm 9.479 \\
\hline Survival \% & $3.77 \mathrm{a}$ & $23.77 \mathrm{~b}$ & $13.78 \mathrm{a}$ \\
& \pm 2.011 & \pm 13.876 & \pm 13.068 \\
\hline
\end{tabular}

Data with different superscripts are significantly different $(\mathrm{P}<0.05)$

\section{Discussion}

The total weight increase was recorded in all the used treatments, while the treatment $\mathrm{T} 2$ (fish fed on a diet containing omega-3) showed the highest rate of total and daily weight gain compared with vitamin E addition and control, Al-Dubakel et al.(2012) use Roquette oil as an additive in the diet of common carp young's and recorded high weight increase due to this addition. It was clear from the above results that the best weight increase achieved when omega-3 offered under the conditions of rearing in the earthen ponds. The least weight increase was recorded from the treatment $\mathrm{T} 1$. The use of omega-3 seems to have improved the nutritional value of the experiment diet. Dietary lipid is more important energy source than carbohydrate in feeding of carnivorous fish and has sparing function on dietary protein (Lee et al., 2002). Perhaps the reason is that lipase is more effective than amylase also fat have the effect of providing protein for growth superior than carbohydrates. Madsen et al. (1999) showed that DHA performs many important functions in fish, including metabolism, and that its presence in cellular membranes regulates the integrity and function of the membrane. Taşbozan \& Gokce (2017) pointed that studies on freshwater fish have shown that their n-3 EFA requirements are mostly focused on linolenic acid (18:3n-3). Consuming enough fatty acids ensures not only that immune cells were built robustly, but also that they work 


\section{Salih et al. / Basrah J. Agric. Sci., 33(1): 200-212, 2020}

more effectively as well (Copeman et al., 2002).

In an experiment conducted by Tidwell \& Robinette (1990) who added palm oil as a source of omega- 6 and fish oil as a source of omega-3 in channel catfish Ictalurus punctatus diets at $1.5 \%$ and $1 \%$ respectively and achieved similar values in the overall weight increase. This was indicated by many studies (Bogut et al. 2002; Ji et al., 2009; Al-Souti et al., 2012 ), who emphasized that diets containing polyunsaturated fatty acids (PUFA) will inhibit the enzymatic activity in Lipogenesis (the metabolism process by which the acetyl-COA is converted into triglycerides and stored in fats), or stored fat in the liver and consequently the fatty acids had a positive impact in the defense of anti-oxidant systems in fishes. However, it has been noted that the absorption of polyunsaturated fatty acids (PUFAs) in fish diet (especially EPA and DHA) will increase the oxidative stress (OS) which may affects normal physiological function (Jin et al., 2017). on the other hand ALA $\alpha$-linolenic acid (ALA, C18:3n-3) has an important physiological function, since it is an essential fatty acid for freshwater fish (Yu et al., 2019).

The needs of common carp and grass carp from omega-6 and omega-3 were studied, it was found that grass carp when fed on diets without essential fatty acids showing symptoms of deficiency, including curvature of the spine and low growth rates, therefore, the proportion of protein digestibility must be appropriate with the ability to digest fats to achieve a high growth rate and efficiency in feed conversion rate (Takeuchi et al., 1980; Yang et al., 2008; Xu et al., 2017).
Results also indicated that the addition of Vit. E had an important role in enhancing rates of total and daily weight gain of common carp, the reason may be in strengthening the antioxidant regimen as the main function of Vit. $\mathrm{E}$ is to prevent the formation of peroxides for unsaturated fatty acids and thus protect against oxidation, especially the membranes of fat cells, which gives more vitality for the functioning of a living cells (Sharifzadeh et al., 2015). As unsaturated fatty acids are important structural components of living cells, including cell specificity, fluidity, elasticity, permeability, and efficacy of cell enzyme binding processes (Stillwell \& Wassall, 2003). Although adding vitamin $\mathrm{E}$ did not differ significantly from control in most parameters, it resulted in a higher weight gain, and this shows its importance in fish diets, Pan et al. (2017) indicated that a lack of Vit. E supplementation in the diet leads to a decrease in the growth rates, and weakens the immune function of young grass carp, but adding Vit. E in the ideal proportions to the diet will lead to altering these negative effects.

The requirements of some fish species from Vit. E range between 120 mg.kg-1 diet (Hamre \& Lie, 1995) to more than $550 \mathrm{mg} . \mathrm{kg}-1$ (Ruff et $a l ., 2003)$ for performance the optimal growth and disease resistance. However increasing the concentration of vitamin $\mathrm{E}$ in a $30 \%$ lipid feed from 300 to $1500 \mathrm{mg} . \mathrm{kg}-1$ diet can reduce the rate of lipid oxidation in fish fillets and reduce the formation of off flavours (Chaiyeapechara et al., 2003). However some research indicated that adding Vit. E to fish diets does not affect growth performance (Forster et al., 1988; Mourente et al., 2000; Li et al., 2008). 


\section{Salih et al. / Basrah J. Agric. Sci., 33(1): 200-212, 2020}

Results of statistical analysis showed that specific and the relative growth rate for the treatment omega-3 differ significantly compared to Vit. E and control treatments. These results are consistent with what Morson \& Clandinin (1986) indicated, as there is a biomechanical mechanism in which essential fatty acids may affect metabolic pathways and their ability to act as effects in all activities of other enzymes related to metabolic pathways that has a vital role in improving the growth. Bou et al. (2017) indicated that the diet containing PUFA n-3 (0. 2-0.5\%) improved the specific growth rate of Atlantic salmon (Salmo salar) compared to fish fed on a PUFA n-3 fatty acid-free diet. Jalali et al. (2008) found that final weight, daily growth rate, specific growth rate and weight gain were higher in beluga (Huso huso) larvae fed with vitamin $\mathrm{E}$ and highly unsaturated fatty acid (HUFA).

\section{Conclusion}

It was concluded from the present study that addition of both omega- 3 and Vit. E to the diet of common carp enhance the growth of brood stock and increase larval survival rate compared to diets without these additives.

\section{Acknowledgments}

The authors acknowledge the Basrah Agricultural Directorate and Aquaculture Unit for all supports and assistance to complete this research work.

\section{References}

Al-Dubakel, A.Y.; Al-Lami, J.H. \& Saber S.H. (2012).The use of Roquette oil (Eruca sativa) as food additive in the Common carp young's diets (Cyprinus carpio L.) and its effects on its characterize. Basrah J. Agric.Sci., 25(2): 72-83. (In Arabic).

https://www.iasj.net/iasj?func=fulltext\&aId=69 133

Al-Souti, A.; Al-Sabahi, J.; Soussi, B. \& Goddard, S. (2012). The effects of fish oilenriched diets on growth, feed conversion and fatty acid content of red hybrid tilapia, Oreochromis sp. Food Chem., 133(3): 723727.

https://doi.org/10.1016/j.foodchem.2012.01. 080

Bezard, J.; Blond, J.; Bernard, A. \& Clouet, P. (1994). The metabolism and availability of essential fatty acids in animal and human tissues. Reprod. Nutr. Dev., 34(6): 539-568. https://doi.org/10.1051/rnd:19940603.

Bogut, I., Has, S.; Elizabeta., Čačić, M.; Milaković, Z.; Novoselić, D. \& Brkić, S. (2002). Linolenic acid supplementation in the diet of European catfish (Silurus glanis): effect on growth and fatty acid composition. J. Appl. Ichthyol., 18(1): 1-6. https://doi.org/10.1046/j.1439-

0426.2002.00304.x

Bou, M.;Berge, G. M.; Baeverfjord, G.; Sigholt, T.; Østbye, T.-K.;Romarheim, O.H.; Hatlen, B.; Leeuwis, R.; Venegas, C. \& Ruyter, B. (2017). Requirements of $n$-3 very long-chain PUFA in Atlantic salmon (Salmo salar L): effects of different dietary levels of EPA and DHA on fish performance and tissue composition and integrity. Brit. J. Nutr., $\quad$ 117(1): 30-47. https://doi.org/10.1017/S0007114516004396

Burdge, G.C., Jones, A.E. \& Wootton, S.A. (2002). Eicosapentaenoic and docosapentaenoic acids are the principal products of $\alpha$-linolenic acid metabolism in young men. Brit. J. Nutr., 88(4): 355-363. 


\section{Salih et al. / Basrah J. Agric. Sci., 33(1): 200-212, 2020}

https://www.iasj.net/iasj?func=fulltext\&aId= 69133

https://www.iasj.net/iasj?func=fulltext\&aId= 69133 https://doi.org/10.1079/BJN2002662

Chaiyeapechara, S.; Casten, M.T.; Hardy, R.W. \& Dong, F.M. (2003). Fish performance, fillet characteristics, and health assessment index of rainbow trout (Oncorhynchus mykiss) fed diets containing adequate and high concentrations of lipid and vitamin $\mathrm{E}$. Aquaculture, 219, 715-738. https://doi.org/10.1016/S00448486(03)00025-5

Copeman, L.; Parrish, C.; Brown, J. \& Harel, M. (2002). Effects of docosahexaenoic, eicosapentaenoic, and arachidonic acids on the early growth, survival, lipid composition and pigmentation of yellowtail flounder (Limanda ferruginea): A live food enrichment experiment. Aquaculture, 210(14): 285-304. https://doi.org/10.1016/S00448486(01)00849-3

FAO. (2018). Food and Agriculture Organization of the united nations . The state of the world Fisheries and Aquaculture FAO. Rome, Licence: CC BY-NC-SA 3.0 IGO:

210pp.

https://creativecommons.org/licenses/by-ncsa/3.0/igo

Forster, I.; Higgs, D.A.; Bell, G.R.; Dosanjh, B. \& March, B. (1988). Effect of diets containing herring oil oxidized to different degrees on growth and immunocompetence of juvenile coho salmon (Oncorhynchus kisutch). Can. J.Fish. Aquat. Sci., 45(12): 2187-2194 . https://doi.org/10.1139/f88-254

Frischknecht, R., Wahli, T. \& Meier, W. (1994). Commparsion of Pathological changes due to definciencyof vitamine $\mathrm{C}$ and vitamine $\mathrm{E}$ and combination of vitamine $\mathrm{C}$ and $\mathrm{E}$ in rainbow trout Oncorhynchus mykiss (Waboum). J. Fish Dis., 17(1): 3-45. https://doi.org/10.1111/j.13652761.1994.tb00343.x

Jalali, M.A.; Hosseini, S.A. \& Imanpour, M. R. (2008). Effect of vitamin $\mathrm{E}$ and highly unsaturated fatty acid-enriched Artemia urmiana on growth performance, survival and stress resistance of Beluga (Huso huso) larvae. Aquac. Res.., 39(12): 1286-1291. https://doi.org/10.1111/j.1365-

2109.2008.01992.x

Ji, H.; Cao, Y.; Liu, P.; Su, S.; Lin, Y.; Cao, F.; Hiromi, O.; Zhou, J. \&Ye, Y. (2009). Effect of dietary HUFA on the lipid metabolism in grass carp Ctenopharymgodon idella. Acta Hydrobiol. Sin., 33(5): 881-889. https://doi.org/10.3724/SP.J.1035.2009.5088 1.

Jin, M.; Yuan, Y.; Lu,Y.; Ma, H.; Sun, P.; Li, Y.; Qiu, H.; Ding, L. \& Zhou, Q. (2017). Regulation of growth, tissue fatty acid composition, biochemical parameters and lipid related genes expression by different dietary lipid sources in juvenile black seabream, Acanthopagrus schlegelii. Aquaculture, 479: 25-37. https://doi.org/10.1016/j.aquaculture.2017.0 5.017

Hamre, K. \& Lie, O. (1995). Minimum requirement of vitamin $\mathrm{E}$ for Atlantic salmon (Salmo salar L.) at first feeding. Aquac. $\quad$ Res., 26: 175-184. https://doi.org/10.1111/j.13652109.1995.tb0 0900.x

Lee, S.M.; Jeon, I.G. \& Lee, J.Y. (2002). Effects of digestible protein and lipid levels in practical diets on growth, protein utilization and body composition of juvenile rockfish (Sebastes schlegeli). Aquaculture, 
Salih et al. / Basrah J. Agric. Sci., 33(1): 200-212, 2020

211(1/4):

$227-$

239.http://doi.org/10.1016/s0044-

486(01)00880-8

Li, P.; Wang, X. \& Gatlin, D.M. (2008). RRR$\alpha$-Tocopheryl succinate is a less bioavailable source of vitamin $E$ than all-rac- $\alpha$ tocopheryl acetate for red drum, Sciaenops ocellatus. Aquaculture, 280(1-4): 165-169. https://doi.org/10.1016/j.aquaculture.2008.0 4.027

New, M.B. (1987). Feed and feeding of fish and shrimp: A manual on the preparation and presentation of compound feeds for shrimp and fish in aquaculture UNEP/ FAO/ ADCP/ $\mathrm{REP} / 87 / 26$

Rome/Italy www.fao.org/docrep/s4314e/s4314e00.htm\# Contents

Madsen, L.; Rustan, A.C.; Vaagenes, H.; Berge, K.; Dyrøy, E. \& Berge, R.K. (1999). Eicosapentaenoic and docosahexaenoic acid affect mitochondrial and peroxisomal fatty acid oxidation in relation to substrate preference. Lipids, 34(9): 951-963. https://doi.org/10.1007/s11745-999-0445-X

Morson, L.A. \& Clandinin, M.T. (1986). Diets varying in linoleic and linolenic acid content alter liver plasma membrane lipid composition and glucagon-stimulated adenylate cyclase activity. J.Nutr., 116(12): 2355-2362.

https://doi.org/10.1093/jn/116.12.2355

Mourente, G.; Díaz-Salvago, E.; Tocher, D.R. \& Bell, J.G. (2000). Effects of dietary polyunsaturated fatty acid/vitamin $\mathrm{E}$ (PUFA/tocopherol ratio on antioxidant defence mechanisms of juvenile gilthead sea bream (Sparus aurata L., Osteichthyes, Sparidae) Fish Physiol. Biochem., 23(4): 337-351.

https://doi.org/10.1023/A:1011128510062
Myszkowski, L. (1997). Pitfalls of using growth rate coefficients. Polskie Archiwum Hydrobiologii, 3(44): 389-396. (Cited by Kwiatkowski, M.; Żarski, D.; Kucharczyk, D.; Kupren, K., Jamróz, M.; Targońska, K.; Krejszeff, S.; Hakuć-Błażowska, A.; Kujawa, R. \& Mamcarz, A. (2008). Influence of feeding natural and formulated diets on chosen rheophilic cyprinid larvae. Arch. Polish Fish., 16(4): 383-396.

https://www.researchgate.net/deref/http\%3A\%2 F\%2Fdx.doi.org\%2F10.2478\%2Fs10086008-0026-0

Pan, J.-H; Feng, L.; Jiang, W.-D.; Wu, P.; Kuang, S.-Y.; Tang, L.; Zhang, Y.-A.; Zhou, X.-Q. \& Liu, Y. (2017). Vitamin E deficiency depressed fish growth, disease resistance, and the immunity and structural integrity of immune organs in grass carp (Ctenopharyngodon idella): Referring to NF- $\kappa$, TOR and Nrf2 signaling. Fish Shellfish Immun., 60: 219-236. https://doi.org/10.1016/j.fsi.2016.11.044

Puangkaew, J.; Kiron, V.; Satoh, S. \& Watanabe, T. (2005). Antioxidant defense of rainbow trout (Oncorhynchus mykiss) in relation to dietary $n-3$ highly unsaturated fatty acids and vitamin $\mathrm{E}$ contents. Comp. Bioch. Phys. C, 140(2): 187-196. https://doi.org/10.1016/j.cca.2005.01.016

Ramezani, F.; Kamarudin, M.S.; Harmin, S.A. \& Saad, C.R. (2012). Dietary saturated and omega-3 fatty acids affect growth and fatty acid profiles of Malaysian Mahseer. Eur. J. Lipid Sci. Techn., 114(2): 185-193. https://doi.org/10.1002/ejlt.201100254

Ruff, N.; Fitzgerald, R.D.; Cross, T.F.; Hamre, K. \& Kerry, J.P. (2003). The effect of dietary vitamin $\mathrm{E}$ and $\mathrm{C}$ level on market-size turbot (Scophthalmus maximus) fillet 
quality. Aquac. Nutr., 9(2): 91-103. https://doi.org/10.1046/j.1365-

2095.2003.00230.x

Sargent, J.; McEvoy, L. \& Bell, J. (1997). Requirements, presentation and sources of polyunsaturated fatty acids in marine fish larval feeds. Aquaculture, 155(1-4): 117127.https://doi.org/10.1016/S00448486(97)00122-1

Sen, C.K.; Khanna, S. \& Roy, S. (2006). Tocotrienols: vitamin E beyond tocopherols. Life Sci., 78(18): 2088-2098. https://doi.org/10.1016/j.lfs.2005.12.001

Sharifzadeh, S.; Khara, H. \& Ghobadi, S. (2015). Effects of vitamin $\mathrm{E}$ and riboflavin (B 2) and their combination on growth and survival of common carp,Cyprinus carpio fingerlings. J. Fish. Aquat. Sci., 10(1): 6368. http://dx.doi.org/10.3923/jfas.2015.63.68

Simopoulos, A.P. (2016). An increase in the omega-6/omega-3 fatty acid ratio increases the risk for obesity. Nutrients, 8(3): 128. https://doi.org/10.3390/nu8030128

Stillwell, W. \& Wassall, S.R. (2003). Docosahexaenoic acid: membrane properties of a unique fatty acid. Chem. Phys. Lipids, 126(1): 1-27. https://doi.org/10.1016/S00093084(03)00101-4

Takeuchi, T.; Arai, S.; Watanabe, T. \& Shimma, Y. (1980). Requirement of eel Anguilla japonica for essential fatty acids. Bull. Jap. Soc. Sci. Fish., 46(3): 345-353. https://doi.org/10.2331/suisan.46.345

Taşbozan, O. \& Gokce, M.A. (2017). Fatty Acids in Fish.143-159. In Catala, A. (Ed.). Fatty Acids. 1st ed. In Tech: Croatia, 248pp.https://www.intechopen.com/books/fa tty-acids/fatty-acids-in-fish

Tidwell, J.H. \& Robinette, H.R. (1990). Changes in proximate and fatty acid composition of fillets from channel catfish during a two year growth period. Trans. Am. Fish. Soc., 119(1): 31-40. https://doi.org/10.1577/1548-

8659(1990)119\%3C0031:CIPAFA\%3E2.3. $\mathrm{CO} ; 2$

Xu, Y.; Li, W. \& Ding, Z. (2017). Polyunsaturated fatty acid supplements could considerably promote the breeding performance of carp. Eur. J. Lipid Sci. Tech., $119(5)$ : 1600183. https://doi.org/10.1002/ejlt.201600183

Yu, J.; Li, S.; Niu, H.; Chang, J.; Hu, Z. \& Han, Y.(2019). Influence of dietary linseed oil as substitution of fish oil on whole fish fatty acid composition, lipid metabolism and oxidative status of juvenile Manchurian trout, Brachymystax lenok. Sci. Rep., 9(1): 1-10. https://doi.org/10.1038/s41598-01950243-8

Zhang, X.; Ning, X.; He, X; Sun, X.; Yu, X.; Cheng, Y.; Yu, R. \& Wu, Y. (2020). Fatty acid composition analyses of commercially important fish species from the Pearl River Estuary, China. PLOS ONE, 15(1): e0228276.

https://doi.org/10.1371/journal.pone.022827 6 
Salih et al. / Basrah J. Agric. Sci., 33(1): 200-212, 2020

\title{
تأثير اضافة الاحماض الدهنية أوميغا 3 (EPA / DHA) وفيتامين Eلى أداء النمو وأداء يرقات Cyprinus) carpio L.
}

\author{
اسامة عبد الهادي صالح1 وعادل يعقوب الدبيكل2 وعلي اسماعيل جودة3 \\ 1 مديرية زر اعة البصرة، وزارة الزر اعة ، العراق \\ 2 وحدة الاستزر اع المائي، 3قسم الاسماك و الثروة البحرية، كلية الزراعة، جامعة البصرة، العراق \\ 3قسم الاسماك والثروة البحرية، كلية الزراعة، جامعة البصرة، العراق
}

المستخلص: أجريت هذه الدراسة في الأحواض الترابية في مفقس الروبيان التابع لمديرية زراعة البصرة، لمعرفة تأثير استخدام الاضافات الغذائية أوميغا 3 وفيتامين El على أداء نمو ونوعية اليرقات المنتجة من اسماك الكارب الثائع . Cyprinus carpio L.

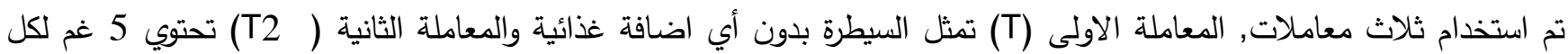
كغم من العليقة على الاحماض الدهنية أوميغا 3 والمعاملة الثالثة (T3) تحتوي 200 ملغم لكل كغم من العليقة على فيتامين E. استمرت التجربة لمدة 82 يومًا. استخدم لكل معاملة ثلاث مكررات وستة اسماك من امهات الكارب الثائع في كل مكرر. تم قياس المقاييس الإنتاجية (وزن الجسم والزيادة الوزنية ومعدل التحويل الغذائي ونسبة كفاءة التغذية ومعدل النمو النسبي والنمو النوعي).

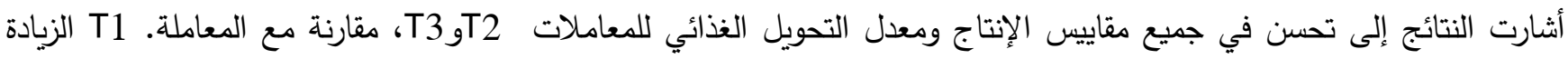
الوزنية (526.39 غم لكل سمكة) و معدل التحويل الغذائي 3.61 ونسبة كفاءة التغذية 28.13٪ للمعاملة T2 والتي أظهرت اختلافات معنوية (P >05 ) مقارنة بمعاملة السيطرة ، بينما لم تظهر المعاملة T3 فروقات معنوية (P> 0.05 ) مقارنة بكل من المعاملتين T1 و T2. كانت معدلات النمو النوعي والنمو النسبي للمعاملة T2 0.32\% لكل يوم و 30.81 \% على التوالي والتي اظهرت ايضا اختلافات معنوية (P >050) مقارنةً بمعاملة السيطرة. أظهرت الدراسة الحالية أن إضافة 3 فيتامين E الى الى العليقة ادى إلى تحسين معايير إنتاج يرقات الكارب الثائع بثكل أفضل مما هو عليه في حالة اضافة أوميغا 3 ومعاملة السيطرة. يستنتج من الدراسة الحالية إلى أن إضافة الأحماض الدهنية أوميغا 3 بتركيز 5 غم لكل كغم وفيتامين E بتركيز 200 ملغم لكل كغم الى على علئق الكارب الثائع يؤدي الى تعزيز معدلات النمو وتحسين إنتاج اليرقات. الكلمات المفتاحية: Cyprinus carpio, الكارب الثائع, الاحماض الدهنية اوميغا-3 (EPA) / DHA), فيتامين E. 